EVALUASI, 5 (1), Maret 2021, ISSN 2580-3387 (print) |

ISSN 2615-2886 (online)

Homepage : http://e-journal.staima-alhikam.ac.id/index.php/evaluasi

DOI : : http://doi.org/10.32478/evaluasi.v5i1.487

Article type : Original Research Article

\title{
EVALUASI PEMBELAJARAN UJIAN AKHIR SEMESTER MATA PELAJARAN BISNIS ONLINE KELAS XII SMK SUNAN DRAJAT LAMONGAN
}

\author{
Miftachul Ulum, Abdul Mun'im, Erly Juliyani, Pusvyta Sari \\ Institut Pesantren Sunan Drajat Lamongan, Indonesia
}

\section{Abstract}

At the end of each semester in an education unit, a learning evaluation is always carried out. One form of learning evaluation in schools is to carry out final semester exams. This study aims to determine the quality of online business lesson items for class XII SMK Sunan Drajat Lamongan in the odd semester 2017/2018 academic year in terms of validity, reliability, difficulty level and difference tests. This quantitative research is based on data from 21 student answer sheets from 25 multiple choice questions. The use of SPSS and Anates V4 software was used to measure the level of validity, reliability, difficulty level and item difference. The results showed that the validity value obtained was 15 items (60\%) were declared invalid and 10 items (40\%) were declared valid. Reliability of the items with a Cronbach Alpha value of $0.640>0.6$, which means that the instrument of the 25 items was declared reliable. The level of difficulty of the tested items obtained 5 items in the very easy category, 10 items in the easy category and 10 items in the moderate category. Of the 25 items, 8 items (32\%) are good, 7 (28\%) are sufficient and 10 (40\%) are bad.

Keywords: Validity, Reliability, Level of Difficulty, Distinction Power

\begin{abstract}
Abstrak
Setiap akhir semester pada satuan pendidikan selalu dilaksanakan evaluasi pembelajaran. Salah satu bentuk evaluasi pembelajaran di sekolah adalah dengan melaksanakan ujian akhir semester. Penelitian ini bertujuan untuk menentukan kualitas butir soal pelajaran bisnis online kelas XII SMK Sunan Drajat Lamongan pada tahun pelajaran 2017/2018 semester ganjil dalam hal tingkat validitas, reliabilitas, tingkat kesukaran dan uji beda. Penelitian kuantitatif ini bersumber pada data 21 lembar jawaban siswa dari 25 butir soal pilihan ganda.
\end{abstract}

Corresponding author: drajatulum@insud.ac.id

EVALUASI: Jurnal Manajemen Pendidikan Islam is licensed under

The CC BY License (https://creativecommons.org/licenses/by-sa/4.0/) 
Homepage : http://e-journal.staima-alhikam.ac.id/index.php/evaluasi

DOI : : http://doi.org/10.32478/evaluasi.v5i1.487

Article type : Original Research Article

Penggunaan software SPSS dan Anates V4 digunakan untuk mengukur tingkat validitas, reabilitas, tingkat kesukaran dan daya beda butir soal. Hasil penelitian diperoleh nilai validitas diperoleh 15 butir soal ( 60\% ) dinyatakan tidak valid dan 10 butir soal ( 40\%) dinyatakan valid. Reliabilitas butir soal dengan nilai Cronbach Alpha sebesar 0,640 > 0,6 yang berarti instrumen butir soal dari 25 butir soal dinyatakan reliabel. Tingkat kesukaran dari butir soal yang diujikan diperoleh 5 butir soal dikatagorikan sangat mudah, 10 butir soal dikatagorikan mudah dan 10 butir soal dikatagorikan sedang. Dari 25 butir soal dapat dikelompokkan 8 butir soal ( $32 \%$ ) baik , 7 butir soal ( $28 \%$ ) cukup dan 10 ( $40 \%$ ) butir soal jelek.

Kata kunci : Validitas, Reliabilitas, Tingkat Kesukaran, Daya Beda

\section{A. PENDAHULUAN}

Proses kegiatan dalam pembelajaran sangat erat sekali dalam mewujudkan kualitas pendidikan disekolah. Kegiatan pembelajaran harus ditunjang dengan fasilitas dan perencananan yang baik sehingga hasil yang diharapkan dapat tercapai. Dalam proses pembelajaran perlu ditetapkan tujuan dari pengajaran, pengalaman belajar dan hasil belajar yang akan dicapai. Ketiga komponen tersebut merupakan tiga unsur dalam pembelajaran. Dalam proses belajar mengajar (pengalaman belajar) kegiatan penilaian merupakan bagian dalam proses belajar mengajar. Kegiatan penilaian adalah kegiatan evaluasi dari proses belajar mengajar yang dilakukan oleh guru untuk memantau proses kegiatan belajar, kemajuan pembelajaran dan perbaikan hasil belajar peserta didik secara keseluruhan ${ }^{1}$. Abdur Razaq mengatakan bahwa keberhasilan siswa dapat diukur dalam proses pembelajaran dikelas dikarenakan proses belajar mengajar yang dapat meningkatkan minat dan motivasi dalam menjalani proses belajar ${ }^{2}$.

${ }^{1}$ Sukardi, Evaluasi Pendidikan Prinsip dan Operasionalnya (Jakarta: Bumi Aksara, 2011).

${ }^{2}$ Abdul Razaq Ahmad Irwan Fariza, Mohd Mahzan Awang, "The Relationship between Students' Involvement in 21st Century Classroom Learning Activities and Higher Order Thinking Skills (Hubungan antara Keterlibatan Pelajar dalam Aktiviti Pembelajaran Abad ke-21 dan Kemahiran Berfikir Aras Tinggi)," Jurnal Pendidikan Malaysia 44, no. 1 (2019): 59-64. 
Homepage : http://e-journal.staima-alhikam.ac.id/index.php/evaluasi

DOI : : http://doi.org/10.32478/evaluasi.v5i1.487

Article type : Original Research Article

Kegiatan evaluasi pembelajaran merupakan tolak ukur dari tercapainya suatu tujuan. Suharsini Arikunto mengatakan evaluasi adalah kegiatan mengukur dan mengumpulkan data untuk mengetahui sejauh mana tujuan telah tercapai ${ }^{3}$. Kegiatan evaluasi dilakukan seorang guru bertujuan untuk mengetahui tingkat pencapaian prestasi siswa dalam mengelola dan menjalankan tugasnya. Evaluasi berarti mampu mengetahui kelemahan siswa dalam proses pembelajaran. Evaluasi yaitu mengukur dengan membandingkan sesuai dengan standar yang telah ditetapkan yang bersifat kuantitatif. Evaluasi juga berarti mengambil keputusan dengan standar baik atau buruk yang bersifat kualitatif. Wringstone mengatakan bahwa evaluasi pendidikan adalah penaksiran terhadap kemajuan dan pertumbuhan siswa menuju arah dan tujuan-tujuan yang telah ditetapkan didalam kurikulum sebelumnya ${ }^{4}$. Sedangkan pelaksanaan evaluasi pembelajaran dapat dilakukan saat pelaksanan pembelajaran sedang berlangsung, tengah semester atau akhir semester.

Bentuk evaluasi dalam pembelajaran dengan pemberian tugas, tes tulis atau praktek. Pemberian tes dalam setiap akhir pembelajaran merupakan alat ukur atas keberhasilan dalam pembelajaran. Tes merupakan bagian yang terkecil atau tersempit dari suatu penilaian. Suharsini Arikunto menyatakan bahwa tes adalah prosedur atau alat yang digunakan untuk mengetahui dan mengukur dengan cara dan aturan yang telah ditentukan sebelumnya ${ }^{5}$. Djemari Mardapi mengatakan tes adalah salah satu alat untuk mengukur tingkat kemampuan siswa secara tidak langsung dengan melalui respon pertanyaan ${ }^{6}$. Dari beberapa pendapat diatas dapat disimpulkan bahwa evaluasi adalah proses mengukur hasil belajar yang meliputi prestasi peserta didik dalam proses pembelajaran yang meliputi awal hingga akhir dari proses pembelajaran.

Pelaksanaan evaluasi yang dilaksanakan dalam pembelajaran ingin menjamin apakah kegiatan yang dilaksanakan dalam pembelajaran telah memenuhi standar yang telah ditetapkan. Zainul Arifin mengapresiasikan dari

${ }^{3}$ Suharsimi Arikunto, Dasar-dasar Evaluasi Pendidikan, 2 ed. (Jakarta: Bumi Aksara, 2013), 40.

4 Ngalim Purwanto, Prinsip-prinsip dan Teknik Evaluasi Pengajaran (Bandung: PT Remaja Rosdakarya, 2013), 3.

${ }^{5}$ Suharsimi Arikunto, Dasar-dasar Evaluasi Pendidikan, 40.

6 Djemari Mardapi, Teknik Penyusunan Instrumen Tes dan Nontes (Yogyakarta: Mitra Cendikia, 2008), 67. 
Homepage : http://e-journal.staima-alhikam.ac.id/index.php/evaluasi

DOI : : http://doi.org/10.32478/evaluasi.v5i1.487

Article type : Original Research Article

pelaksanaan evaluasi pembelajaran bertujuan untuk mengetahui efisiensi dan efektifitas dalam sistem pembelajaran yang meliputi materi, metode , media, sumber belajar, sistem penilaian dan lingkungan belajar ${ }^{7}$. Sistem pembelajaran yang dikembangkan dalam satuan lembaga pendidikan berbeda-beda. Perbedaan sistem pembelajaran yang berbeda sangat bergantung dari visi dan misi setiap satuan lembaga pendidikan. Suharsini Arikunto memaparkan beberapa fungsi dari evaluasi belajar. 1. Fungsi selektif yaitu digunakan untuk menyeleksi siswa yang naik kelas, siswa yang lulus dan siswa yang berhak mendapatkan beasiswa prestasi. 2. Fungsi diagnostik yaitu mengetahui kelemahan dan kelebihan peserta didik, sehingga dengan mengetahui kelemahan maka akan memudahkan mencarikan solusi cara mengatasinya. 3. Fungsi penempatan yaitu menentukan kelompok mana siswa tersebut dapat dikelompokkan dalan katagori yang sama atas kemampuan yang dimilikinya. 4. Fungsi keberhasilan yaitu mengetahui sejauh mana program yang telah direncanakan dapat tercapai ${ }^{8}$.

Pelaksanaan evaluasi yang dilaksanakan oleh guru terhadap peserta didik haruslah dapat menjamin perubahan dari setiap evaluasi yang dilakukannya. Pelaksanaan dalam setiap evaluasi menunjukkan tingkat antisipasi atas kekurangan dan kelemahan selama pelaksanaan pembelajaran. Anas Sudijono menyampaikan pelaksanaan evaluasi belajar dapat dikatakan baik bila pelaksanaan evaluasi menerapkan 3 prinsip dasar yaitu (1). Prinsip komprehensif yaitu evalusi harus dilaksankan secara keseluruhan yang harus mencakup aspek perkembangan atau perubahna perilaku yang terjadi pada peserta didik, (2). Prinsip kesinambungan yaitu evalusi harus dilaksankan secara teratur dari waktu ke waktu, (3).Prinsip objektif yaitu evalusi harus dijauhkan dari faktor subjektif dari guru dan memperlakukan peserta didik secara wajar ${ }^{9}$.

Dariyanto mengatakan beberapa prinsip yang harus dimiliki oeh seorang pendidik dalam memerankan sebagai seorang evaluator yaitu (1). Keterpaduan antara perencanaan evaluasi dalam penyusunan satuan pengajaran dengan tujuan pembelajaran dan materi pengajaran, (2). 2013), 14.

7 Zainal Arifin, Evaluasi Pembelajaran (Bandung: PT Remaja Rosdakarya,

${ }^{8}$ Suharsimi Arikunto, Dasar-dasar Evaluasi Pendidikan, 10.

${ }^{9}$ Anas Sudijono, Pengantar Evaluasi Pendidikan (Jakarta: PT Raja Grafindo Persada., 2011), 209. 
Homepage : http://e-journal.staima-alhikam.ac.id/index.php/evaluasi

DOI : : http://doi.org/10.32478/evaluasi.v5i1.487

Article type : Original Research Article

Keterlibatan siswa untuk mengetahui keberhasilan menerima materi pembelajaran, (3). Koherensi bahwa materi yang disampaikan dalam pembelajaran harus sesuai dengan ranah kemampuan siswa, (4).Pedagogis yang berarti evaluasi yang dilakukan dapat merubah sikap dan perilaku siswa lebih baik, (5). Akuntabilitas yang berarti evalusi yang dilakukan harus dapat dipertanggungjawabkan kepada semua pihak yang berkepentingan ${ }^{10}$. Salah satu bentuk evaluasi pembelajaran dengan melaksanakan ujian atau tes. Tes juga dapat diartikan sebagai sejumlah pertanyaan yang harus diberikan tanggapan dengan tujuan untuk mengukur tingkat kemampuan seseorang atau mengungkapkan aspek tertentu dari orang yang dikenai tes. Respon peserta tes terhadap sejumlah pertanyaan maupun pernyataan adalah menggambarkan kemampuan peserta tes dalam bidang tertentu. Pemberian butir soal dalam pelaksanaan ujian akhir semester dapat memberikan gambaran tentang evaluasi pembelajaran selama pelaksanan kegiatan belajar mengajar. Keberhasilan peserta didik dalam mengerjakan soal sangat dipengaruhi kualitas soal yang diujikan. Dari gambaran uraian diatas maka peneliti ingin mengetahui kualitas butir soal yang diujikan dilihat dari validitas, reliabilitas, tingkat kesukaran dan uji beda pada pelajaran bisnis online kelas XII SMK Sunan Drajat Lamongan tahun pelajaran 2017/2018 semester ganjil.

\section{B. METODE PENELITIAN}

Penelitian dengan metode kuantitif dilaksanakan di kelas XII SMK Sunan Drajat Lamongan pada mata pelajaran bisnis online dalam akhir semester ganjil tahun pelajaran 2017/2018 . Penilaian dilakukan terhadap lembar jawaban 21 siswa yang telah melaksanakan tes tulis soal pilihan ganda atau multiple choice sebanyak 25 butir soal. Variabel penelitian berupa butir soal pilihan ganda atau multiple choice yang ditinjau dari aspek validitas, reliabilitas, tingkat kesukaran dan daya pembeda dengan menggunakan software SPSS versi 16 dan software Anates V4. Validitas merupakan suatu alat ukur yang digunakan untuk mengetahui sejauhmana alat ukur itu mampu mengukur apa yang seharusnya diukur ${ }^{11}$. Analisa uji

${ }^{10}$ Daryanto, Evaluasi Pendidikan (Jakarta: PT Rineka Cipta, 2008), 21.

11 Miftachul Ulum, Mahir Analisa Data SPSS Statistical Product, Service Solution (Yogyakarta: Ghaneswara, 2013). 
EVALUASI, 5 (1), Maret 2021, ISSN 2580-3387 (print) |

ISSN 2615-2886 (online)

Homepage : http://e-journal.staima-alhikam.ac.id/index.php/evaluasi

DOI $\quad:$ http://doi.org/10.32478/evaluasi.v5i1.487

Article type : Original Research Article

validitas butir soal dapat dilakukan dengan menggunakan teknik poin biserial yaitu :

$$
r_{p b i}=\frac{M_{p}-M_{t}}{S D_{t}} \sqrt{\frac{p}{q}}
$$

Analisa uji validitas butir soal dapat juga dengan menggunakan korelasi product moment ${ }^{12}$ yaitu :

$r=\frac{n \sum(x y)-\left(\sum x\right)\left(\sum y\right)}{\sqrt{ }\left(n\left(\sum x^{2}\right)-\left(\sum x\right)^{2}\right)\left(n\left(\sum y^{2}\right)-\left(\sum y\right)^{2}\right)}$

Penerapan Uji validitas dapat dilakukan dengan menggunakan kreteria pengujian yaitu nilai $r$ hitung akan dibandingkan dengan koefisien korelasi $r$ tabel , jika $r$ hitung $>r$ tabel, maka instrumen butir soal valid. Jika $r$ hitung $<r$ tabel maka instrumen butir soal tidak valid. Uji validitas juga dapat dilakukan dengan membandingkan hasil output pada program SPSS dengan kreteria jika hasil corrected item-total correlation coefficient $r>r$ tabel, maka instrumen valid. Jika corrected item-total correlation coefficient $r<\mathrm{r}$ tabel, maka instrumen valid.

Reliabilitas tes berkenaan dengan pertanyaan apakah suatu tes yang diteliti sesuai dengan kriteria yang telah ditetapkan. Reliabilitas adalah tingkat atau derajat konsistensi dari sebuah instrumen ${ }^{13}$. Suatu instrumen pengukuran dikatakan reliabel jika pengukurannya konsisten, cermat dan akurat. Rumus pengujian uji reliabitas yang dapat digunakan adalah Alfa Cronbach.

$r_{i}=\frac{k}{(k-1)}\left\{1-\frac{\sum s i^{2}}{s t^{2}}\right\}$

12 Miftachul Ulum, BASIC STATISTIC With Statistical Package for Social Sciences (SPSS), 1 ed. (Lamongan: CV. Pustaka Ilalang, 2020).

${ }^{13}$ Zainal Arifin, Evaluasi Pembelajaran. 
EVALUASI, 5 (1), Maret 2021, ISSN 2580-3387 (print) |

ISSN 2615-2886 (online)

Homepage : http://e-journal.staima-alhikam.ac.id/index.php/evaluasi

DOI : : http://doi.org/10.32478/evaluasi.v5i1.487

Article type : Original Research Article

Kreteria pengujian nilai koefesien $(r)$ akan dibandingkan dengan koefesien korelasi tabel $r_{\text {tabel }}$. Jika $r_{\text {hitung }}>r_{\text {tabel }}$, maka instrumen reliabel.Pada Output SPSS, jika Cronbach's Alpha $>r_{\text {tabel }}$,maka instrumen reliabel. Tingkat reliabilitas soal pada rentangan koefesien korelasi dapat di inteprestasikan apabila koefesien $(r)$ lebih besar daripada 0,60 berarti tes hasil belajar yang sedang diuji reliabilitasnya dinyatakan telah memiliki reliabilitas yang tinggi (reliable). Apabila koefesien $(r$ ) lebih kecil daripada 0,60 berarti tes hasil belajar yang sedang diuji reliabilitasnya dinyatakan belum memiliki relibilitas yang tinggi (un-reliable) ${ }^{14}$.

Analisis tingkat kesukaran soal artinya mengkaji soal-soal tes dari segi kesulitannya sehingga dapat diperoleh soal-soal mana yang termasuk mudah, sedang, dan sukar ${ }^{15}$. Angka indeks kesukaran item dapat diperoleh dengan menggunakan rumus sebagai berikut:

$$
P=\frac{B}{J S}
$$

Witherington menafsirkan tingkat kesukaran butir tes yang digunakan dalam kriteria ${ }^{16}$ sebagai berikut :

Tabel 1. Interprestasi tingkat kesukaran butir soal

\begin{tabular}{c|c}
\hline Interval & Interprestasi \\
\hline $0,00-0,30$ & Soal Sukar \\
$0,32-0,70$ & Soal Sedang \\
$0,71-1,00$ & Soal Mudah \\
\hline
\end{tabular}

Penafsiran analisis tingkat kesukaran butir soal dalam Anates sebagai berikut:

Tabel 2. Interprestasi Tingkat Kesukaran Anates

\begin{tabular}{c|c}
\hline Interval & Interprestasi \\
\hline $0 \%-15 \%$ & Sangat Sukar
\end{tabular}

${ }^{14}$ Anas Sudijono, Pengantar Evaluasi Pendidikan, 209.

15 Muslikah Purwanti, “Analysis Of Final Exam Questions In Financial Accounting Using Microsoft Excel 2010,” Jurnal Pendidikan Akuntansi Indonesia XII, no. 1 (2014): 81-94.

${ }^{16}$ Anas Sudijono, Pengantar Evaluasi Pendidikan. 
EVALUASI, 5 (1), Maret 2021, ISSN 2580-3387 (print) |

ISSN 2615-2886 (online)

Homepage : http://e-journal.staima-alhikam.ac.id/index.php/evaluasi

DOI $\quad:$ http://doi.org/10.32478/evaluasi.v5i1.487

Article type : Original Research Article

$$
\begin{gathered}
0 \%-15 \% \\
31 \%-70 \% \\
71 \%-85 \% \\
86 \%-100 \%
\end{gathered}
$$

Sukar

Sedang

Mudah

Sangat Mudah

Daya beda butir soal ialah indeks yang menunjukkan tingkat kemampuan butir soal membedakan kelompok yang berprestasi tinggi (kelompok atas) dari kelompok yang berprstasi rendah (kelompok bawah) diantara para peserta tes ${ }^{17}$. Tujuan pokok mencari daya beda adalah untuk menentukan apakah butir soal tersebut memiliki kemampuan membedakan kelompok dalam aspek yang diukur, sesuai dengan perbedaan yang ada pada kelompok $i \mathrm{it}^{18}$. Suharsini menginteprestasikan daya beda dapat diklasifikasikan sebagai berikut ${ }^{19}$ :

Tabel 3. Interprestasi Daya Beda

\begin{tabular}{c|c}
\hline Interval & Interprestasi \\
\hline $0,00-0,19$ & Jelek \\
$0,20-0,39$ & Cukup \\
$0,40-0,69$ & Baik \\
$0,70-1,00$ & Baik sekali \\
\hline
\end{tabular}

Daya Pembeda juga dapat diklasifikasikan ${ }^{20}$ sebagai berikut :

Tabel 4. Klasifikasi Daya Beda

\begin{tabular}{c|l}
\hline Interval & \multicolumn{1}{|c}{ Interprestasi } \\
\hline Negatif $-9 \%$ & Sangat Buruk, harus diulang \\
$10 \%-19 \%$ & Buruk, sebaiknya dibuang \\
$20 \%-29 \%$ & Cukup baik, perlu direvisi
\end{tabular}

${ }^{17}$ Asmawi Zainul, Penilaian Hasil Belajar (Jakarta: Pusat Antar Universitas, Direktorat Jenderal Pendidikan Tinggi: Departemen Pendidikan Dan kebudayaan, 1997).

${ }^{18}$ Suryabrata, S., Pengembangan Alat Ukur Psikologis (Jakarta: Direktorat jenderal Pendidikan Tinggi: Departemen Pendidikan dan Kebudayaan, 1999).

${ }^{19}$ Suharsimi Arikunto, Dasar-dasar Evaluasi Pendidikan, 218.

${ }^{20}$ Karno To, Mengenal Analisis Tes Pengantar ke Program Komputer Anates (Bandung: FIP UPI, 2003), 14. 
EVALUASI, 5 (1), Maret 2021, ISSN 2580-3387 (print) |

ISSN 2615-2886 (online)

Homepage : http://e-journal.staima-alhikam.ac.id/index.php/evaluasi

DOI $\quad:$ http://doi.org/10.32478/evaluasi.v5i1.487

Article type : Original Research Article

$30 \%-49 \%$

Baik

$50 \%$ - keatas

Sangat Baik

\section{HASIL PENELITIAN DAN PEMBAHASAN}

Data hasil penelitian pada ujian akhir semester mata pelajaran pemasaran online diperoleh, siswa mengerjakan soal dengan benar 13 soal sebanyak 1 orang, 14 soal sebanyak 3 orang, 16 soal sebanyak 1 orang, 17 soal sebanyak 4 orang, 18 soal sebanyak 5 orang, 19 soal sebanyak 1 orang, 20 soal sebanyak 2 orang, 22 soal sebanyak 2 orang, 23 soal sebanyak 1 orang dan 24 soal sebanyak 1 orang. Adapun secara rinci dapat dilihat pada tabel berikut :

Tabel 5. Data Nilai Mata Pelajaran Pemasaran Online Kelas XII

\begin{tabular}{c|c|c}
\hline Jumlah Jawaban Benar & Jumlah Siswa & Nilai \\
\hline 13 & 1 & 52 \\
14 & 3 & 56 \\
16 & 1 & 64 \\
17 & 4 & 68 \\
18 & 5 & 72 \\
19 & 1 & 76 \\
20 & 2 & 80 \\
22 & 2 & 88 \\
23 & 1 & 92 \\
24 & 1 & 96 \\
\hline
\end{tabular}

Nilai terendah yang diperoleh siswa dalam mata pelajaran Pemasaran Online sebesar 44 dan nilai tertinggi 96. Dengan menggunakan program SPSS diperoleh data statisitik sebagai berikut :

Tabel 6. Descriptive Statistics 
EVALUASI, 5 (1), Maret 2021, ISSN 2580-3387 (print) |

ISSN 2615-2886 (online)

Homepage : http://e-journal.staima-alhikam.ac.id/index.php/evaluasi

DOI $\quad:$ http://doi.org/10.32478/evaluasi.v5i1.487

Article type : Original Research Article

$\mathrm{N}$

\begin{tabular}{lccccccrr} 
& & Range & Min & Max & Sum & Mean & Std. Deviation & Variance \\
\hline Jawaban Benar & 21 & 11 & 13 & 24 & 379 & 18.05 & 3.025 & 9.148 \\
Nilai & 21 & 44 & 52 & 96 & 1516 & 72.19 & 12.098 & 146.362 \\
Valid N (listwise) & 21 & & & & & & & \\
\hline
\end{tabular}

Dari data jumlah jawaban benar dan salah dapat dijabarkan soal-soal yang dapat dikerjakan oleh siswa dan soal yang tidak dapat dikerjakan sebagimana terangkum tabel berikut ini :

\begin{tabular}{c|c|c}
\multicolumn{3}{c}{ Tabel 7. Data Jumlah Jawaban benar dan Salah } \\
\hline Nomer Soal & $\begin{array}{c}\text { Jumlah Jawaban } \\
\text { Benar }\end{array}$ & $\begin{array}{c}\text { Jumlah Jawaban } \\
\text { Salah }\end{array}$ \\
\hline 1 & 16 & 5 \\
2 & 18 & 3 \\
3 & 18 & 3 \\
4 & 18 & 3 \\
5 & 13 & 8 \\
6 & 8 & 13 \\
7 & 13 & 8 \\
8 & 11 & 10 \\
9 & 15 & 6 \\
10 & 15 & 6 \\
11 & 17 & 4 \\
12 & 14 & 7 \\
13 & 13 & 8 \\
14 & 17 & 4 \\
15 & 15 & 6 \\
16 & 14 & 7 \\
17 & 16 & 5 \\
18 & 13 & 8 \\
19 & 18 & 3 \\
20 & 14 & 7 \\
21 & 15 & 6 \\
22 & 15 & 6 \\
23 & 17 & 4
\end{tabular}


EVALUASI, 5 (1), Maret 2021, ISSN 2580-3387 (print) |

ISSN 2615-2886 (online)

Homepage : http://e-journal.staima-alhikam.ac.id/index.php/evaluasi

DOI $\quad:$ http://doi.org/10.32478/evaluasi.v5i1.487

Article type : Original Research Article

\begin{tabular}{l|l|l}
24 & 17 & 4 \\
25 & 18 & 3 \\
\hline
\end{tabular}

Nilai validitas dari butir soal dinyatakan valid dengan kreteria jika $r$ hitung $>r$ tabel dan dinyatakan tidak valid dengan kreteria jika $r$ hitung $<r$ tabel. Dengan tingkat taraf signifikan sebesar 0,05 diperoleh nilai $r$ tabel sebesar 0,381. Dengan menggunakan Anates di peroleh nilai validitas dari 25 butir soal dengan diperoleh 10 ( $40 \%$ ) soal dinyatakan valid dan 15 (60\%) dinyatakan tidak valid yang tercermin nilai koefisien korelasi tiap butir soal sebagaimana dalam tabel berikut :

Tabel 8. Nilai Korelasi Butir Soal

\begin{tabular}{c|c|c}
\hline Nomer Soal & Korelasi & Signifikan \\
\hline 1 & 0,123 & \\
3 & 0,145 & Signifikan \\
4 & 0,422 & \\
5 & 0,007 & Signifikan \\
6 & 0,411 & \\
7 & 0,253 & Signifikan \\
8 & 0,411 & Signifikan \\
9 & 0,405 & Signifikan \\
10 & 0,439 & Signifikan \\
11 & 0,422 & \\
12 & 0,254 & Signifikan \\
13 & 0,491 & Sangat Signifikan \\
14 & 0,577 & \\
15 & 0,053 & \\
16 & 0,08 & \\
17 & 0,01 & Sangat Signifikan \\
18 & 0,539 & \\
19 & 0,079 & \\
20 & 0,337 & \\
21 & 0,08 & \\
& &
\end{tabular}


EVALUASI, 5 (1), Maret 2021, ISSN 2580-3387 (print) |

ISSN 2615-2886 (online)

Homepage : http://e-journal.staima-alhikam.ac.id/index.php/evaluasi

DOI $\quad:$ http://doi.org/10.32478/evaluasi.v5i1.487

Article type : Original Research Article

\begin{tabular}{l|c}
22 & 0,312 \\
23 & 0,213 \\
24 & $-0,033$ \\
25 & 0,191
\end{tabular}

Nilai validitas dari butir soal dapat juga dinyatakan dari hasil output program SPSS. Butir soal dinyatakan valid jika nilai corrected item-total correlation coefficient $r>r$ tabel, dan dinyatakan tidak valid jika corrected item-total correlation coefficient $r<\mathrm{r}$ tabel Dengan tingkat taraf signifikan sebesar 0,1 diperoleh nilai $r$ tabel sebesar 0,3233 diperoleh nilai validitas dari 25 butir soal dengan diperoleh 10 ( 40\%) soal dinyatakan valid dan 15 (60\%) dinyatakan tidak valid yang tercermin dari nilai corrected item-total correlation coefficient tiap butir soal dan hasil pengolahan dengan pengolahan SPSS sebagaimana tabel berikut :

Tabel 9 Item-Total Statistics

\begin{tabular}{l|r|r|r|r}
\hline & $\begin{array}{r}\text { Scale Mean if } \\
\text { Item Deleted }\end{array}$ & $\begin{array}{r}\text { Scale Variance } \\
\text { if Item Deleted }\end{array}$ & $\begin{array}{c}\text { Corrected } \\
\text { Item-Total } \\
\text { Correlation }\end{array}$ & $\begin{array}{c}\text { Cronbach's } \\
\text { Alpha if Item } \\
\text { Deleted }\end{array}$ \\
\hline Soal_1 & 35.33 & 36.133 & .051 & .642 \\
Soal_2 & 35.24 & 36.090 & .086 & .639 \\
Soal_3 & 35.24 & 34.890 & .371 & .626 \\
Soal_4 & 35.24 & 36.690 & -.053 & .646 \\
Soal_5 & 35.48 & 34.362 & .340 & .623 \\
Soal_6 & 35.71 & 35.314 & .174 & .634 \\
Soal_7 & 35.48 & 34.362 & .340 & .623 \\
Soal_8 & 35.57 & 33.557 & .467 & .613 \\
Soal_9 & 35.38 & 34.348 & .374 & .622 \\
Soal_10 & 35.38 & 35.148 & .224 & .631 \\
Soal_11 & 35.29 & 35.514 & .191 & .634 \\
Soal_12 & 35.43 & 33.957 & .426 & .617 \\
Soal_13 & 35.48 & 33.362 & .519 & .610 \\
Soal_14 & 35.29 & 35.714 & .149 & .636 \\
Soal_15 & 35.38 & 37.148 & -.137 & .653
\end{tabular}


EVALUASI, 5 (1), Maret 2021, ISSN 2580-3387 (print) |

ISSN 2615-2886 (online)

Homepage : http://e-journal.staima-alhikam.ac.id/index.php/evaluasi

DOI : : http://doi.org/10.32478/evaluasi.v5i1.487

Article type : Original Research Article

\begin{tabular}{l|r|r|r|r} 
Soal_16 & 35.43 & 35.957 & .069 & .641 \\
Soal_17 & 35.33 & 33.933 & .485 & .616 \\
Soal_18 & 35.48 & 36.362 & -.003 & .646 \\
Soal_19 & 35.24 & 35.890 & .133 & .637 \\
Soal_20 & 35.43 & 36.357 & .000 & .645 \\
Soal_21 & 35.38 & 34.348 & .374 & .622 \\
Soal_22 & 35.33 & 35.133 & .245 & .630 \\
Soal_23 & 35.29 & 35.714 & .149 & .636 \\
Soal_24 & 35.29 & 36.914 & -.099 & .649 \\
Soal_25 & 35.24 & 35.890 & .133 & .637 \\
Total_skor & 18.05 & 9.148 & 1.000 & .482 \\
\hline
\end{tabular}

Reliabilitas tes menunjukkan sejauh mana alat ukur yang digunakan dapat dipercaya. Reliabilitas tes merupakan ketepatan atau keajegan alat dalam menilai apa yang dinilai. Reliabilitas menunjukkan kestabilan skor yang diperoleh peserta tes yang sama ketika diuji ulang dengan tes yang sama pada situasi yang berbeda atau dari suatu pengukuran ke pengukuran lainnya.Suatu instrumen dikatakan reliabel jika Cronbach's Alpha > 0,6 Berdasarkan hasil pengolahan dengan program SPSS diperoleh nilai Cronbach Alpha sebesar 0,640 yang berarti diatas nilai ketentuan 0,6 yang berarti Ujian Akhir Semester untuk mata pelajaran bisnin online untuk soal pilihan ganda dari 25 soal dinyatakan instrumen soal reliabel.

Analisa tingkat kesukaran soal merupakan proporsi dari jumlah soal yang mampu di jawab oleh siswa dengan benar. Analisa ini mengkaji soalsoal yang termasuk katagori mudah, sedang dan sulit dijawab. Tingkat kesukaran dipandang dari segi siswa dalam kemampuannya menjawab soal bukan guru dalam kesulitan membuat soal. Berdasarkan hasil analisis tingkat kesukaran dengan software Anates diperoleh tingkat kesukaran dari 25 soal yang tergolong soal sangat mudah sebanyak 5 soal yaitu soal nomer $2,3,4,14$ dan 25 . Soal yang tergolong mudah sebanyak 10 soal yaitu soal nomer 1,9 , $11,16,17,19,21,22,23$, dan 24 . Soal yang tergolong sedang 10 soal yaitu soal nomer $5,6,7,8,10,12,13,15,18$ dan 20. Secara rinci hasil pengolahan dengan menggunakan software Anates diperoleh tingkatan kesukaran sebagaimana tabel 10 . 
EVALUASI, 5 (1), Maret 2021, ISSN 2580-3387 (print) |

ISSN 2615-2886 (online)

Homepage : http://e-journal.staima-alhikam.ac.id/index.php/evaluasi

DOI $\quad:$ http://doi.org/10.32478/evaluasi.v5i1.487

Article type : Original Research Article

Tabel 10 . Tingkat Kesuakaran

\begin{tabular}{c|c|c|l}
\hline Nomer Soal & Jumlah Jawaban Benar & Tingkat Kesukaran & \multicolumn{1}{|c}{ Tafsiran } \\
\hline 1 & 16 & 76,19 & mudah \\
2 & 18 & 85,71 & sangat mudah \\
3 & 18 & 85,71 & sangat mudah \\
4 & 18 & 85,71 & sangat mudah \\
5 & 13 & 61,9 & sedang \\
6 & 8 & 38,1 & sedang \\
7 & 13 & 61,9 & sedang \\
8 & 11 & 57,14 & sedang \\
9 & 15 & 71,43 & mudah \\
10 & 15 & 66,67 & sedang \\
11 & 17 & 80,95 & mudah \\
12 & 14 & 66,67 & sedang \\
13 & 13 & 61,9 & sedang \\
14 & 17 & 85,71 & sangat mudah \\
15 & 15 & 66,67 & sedang \\
16 & 14 & 71,43 & mudah \\
17 & 16 & 76,19 & mudah \\
18 & 13 & 61,9 & sedang \\
19 & 18 & 80,95 & mudah \\
20 & 14 & 66,67 & sedang \\
21 & 15 & 71,43 & mudah \\
22 & 15 & 76,19 & mudah \\
23 & 17 & 80,95 & mudah \\
24 & 17 & 80,95 & mudah \\
25 & 18 & 85,71 & sangat mudah \\
\hline
\end{tabular}

Witherington menafsirkan dalam tingkat kesukaran dari 25 soal yang diujikan dapat disimpulkan bahwa tingkat kesukaran sedang sebanyak 10 soal yaitu soal nomer $5,6,7,8,10,12,13,15,18$, dan 20 . Sedangkan kelompok soal dengan tingkat kesukaran mudah sebanyak 15 soal yaitu soal nomer $1,2,3$, $4,9,11,14,16,17,19,21,22,23,24$, dan 25.

Perbedaan kemampuan dalam menjawab soal sangat bervariasi. Adanya analisa uji beda berfungsi untuk mengkaji soal-soal dilihat dari kesanggupan kemampuan siswa. Uji beda bertujuan mengelompokkan 
EVALUASI, 5 (1), Maret 2021, ISSN 2580-3387 (print) |

ISSN 2615-2886 (online)

Homepage : http://e-journal.staima-alhikam.ac.id/index.php/evaluasi

DOI $\quad:$ http://doi.org/10.32478/evaluasi.v5i1.487

Article type : Original Research Article

kemampuan siswa yang dapat dikelompokkan dalam katagori rendah dan katagori tinggi. Analisis daya beda artinya mengkaji soal-soal tes dari segi kesanggupan tes tersebut dalam membedakan siswa yang termasuk kedalam kategori rendah dan kategori tinggi. Daya pembeda butir adalah kemampuan suatu butir tes untuk dapat membedakan antara testee yang berkemampuan tinggi dan berkemampuan rendah ${ }^{21}$. Analisis daya beda pada penelitian ini menggunakan rumus dan software Anates diperoleh hasil uji beda sebagai berikut :

Tabel 10 . Inteprestasi Uji beda

\begin{tabular}{|c|c|c|}
\hline Nomer Soal & Indeks & Inteprestasi \\
\hline 1 & 0,00 & Jelek \\
\hline 2 & 0,00 & Jelek \\
\hline 3 & 33,33 & Cukup \\
\hline 4 & $-16,67$ & Jelek \\
\hline 5 & 50,00 & Baik \\
\hline 6 & 33,33 & Cukup \\
\hline 7 & 50,00 & Baik \\
\hline 8 & 66,67 & Baik \\
\hline 9 & 33,33 & Cukup \\
\hline 10 & 50,00 & Baik \\
\hline 11 & 33,33 & Cukup \\
\hline 12 & 50,00 & Baik \\
\hline 13 & 66,67 & Baik \\
\hline 14 & 0,00 & Jelek \\
\hline 15 & 16,67 & Jelek \\
\hline 16 & 0,00 & Jelek \\
\hline 17 & 50,00 & Baik \\
\hline 18 & 16,67 & Jelek \\
\hline 19 & 16,67 & Jelek \\
\hline 20 & 16,67 & Jelek \\
\hline 21 & 50,00 & Baik \\
\hline
\end{tabular}

${ }^{21}$ Nuraini Soleiman Dewi Juliah Ratnaningsih, Isfarudi, “Analisis Butir Soal Pilihan Ganda Ujian Akhir Semester Mahasiswa Di Universitas Terbuka Dengan Pendekatan Teori Tes Klasik," Jurnal Pendidikan Terbuka dan Jarak Jauh 12, no. 2 (2011): 93. 
EVALUASI, 5 (1), Maret 2021, ISSN 2580-3387 (print) |

ISSN 2615-2886 (online)

Homepage : http://e-journal.staima-alhikam.ac.id/index.php/evaluasi

DOI : : http://doi.org/10.32478/evaluasi.v5i1.487

Article type : Original Research Article

\begin{tabular}{c|c|c}
22 & 33,33 & Cukup \\
23 & 33,33 & Cukup \\
24 & 0,00 & Jelek \\
25 & 33,33 & Cukup \\
\hline
\end{tabular}

Dari dua puluh lima soal yang diujikan dapat dikatagorikan soal baik 8 butir atau $32 \%$ yaitu butir soal nomer $5,7,8,10,12,13$, dan 21 . Soal dalam katagori cukup 7 atau 28 \% yaitu butir soal nomer 3, 6, 9, 11, 22, 23, dan 25 . Soal dalam katagori jelek 10 butir atau $40 \%$ yaitu butir soal nomer $1,2,4,14$, $15,16,18,19,20$, dan 24 . Fernandes mengatakan dengan Indeks daya beda butir soal dapat digunakan sebagai bahan pertimbangan sebuah butir baik atau tidak baik. Butir soal yang baik adalah butir soal yang mempunyai indeks daya beda lebih dari 0,2. ${ }^{22}$. Sementara Ebel menjelaskan suatu butir soal dikatakan berkualitas apabila indeks diskriminasi atau daya pembedanya paling sedikit $0,41^{23}$. Dari uji beda dalam butir soal dapat ditindak lanjuti terhadap soal yang termasuk katogari jelek untuk yaitu diperbaiki kualitas daya beda soal atau tidak digunakan lagi untuk diujikan. Sedangkan soal yang termasuk katagori daya beda yang baik untuk dapat dipertahankan. Butir soal nomer 4 yang angka indeks diskriminanya bertanda negatif tidak perlu digunakan pada tes hasil belajar atau direvisi kembali

\section{KESIMPULAN}

Hasil penelitian dan pembahasan dapat disimpulkan 15 butir soal ( $60 \%$ ) dinyatakan tidak valid dan 10 butir soal ( $40 \%$ ) dinyatakan valid. Reliabilitas soal dinyatakan reliabel sesuai ketentuan nilai Cronbach Alpha sebesar 0,640 > 0,6 dari 25 butir soal. Tingkat kesukaran dari 25 butir soal dapat kelompokkan 5 butir soal ( $20 \%$ ) sangat mudah, 10 butir soal ( $40 \%$ ) mudah dan 10 butir soal ( $40 \%$ ) sedang. Untuk jenis soal dapat dikatagorikan baik 8 butir soal ( $32 \%$ ), katagori cukup 7 butir soal $\quad$ ( $28 \%$ ) dan katagori jelek 10 butir soal ( $40 \%$ ).

${ }^{22}$ Fernandes, H.J. X., Evaluation of educational program (Jakarta: National Education Planning, Evaluating and Curriculum Development, 1984).

23 Ebel, R.L., Essentials of educational measurement, 3rd ed. (Englewood Cliffts,NJ: Prentice Hall Inc., 1972). 
EVALUASI, 5 (1), Maret 2021, ISSN 2580-3387 (print) |

ISSN 2615-2886 (online)

Homepage : http://e-journal.staima-alhikam.ac.id/index.php/evaluasi

DOI : : http://doi.org/10.32478/evaluasi.v5i1.487

Article type : Original Research Article

\section{REFERENSI}

Anas Sudijono. Pengantar Evaluasi Pendidikan. Jakarta: PT Raja Grafindo Persada., 2011.

Asmawi Zainul. Penilaian Hasil Belajar. Jakarta: Pusat Antar Universitas, Direktorat Jenderal Pendidikan Tinggi: Departemen Pendidikan Dan kebudayaan, 1997.

Daryanto. Evaluasi Pendidikan. Jakarta: PT Rineka Cipta, 2008.

Dewi Juliah Ratnaningsih, Isfarudi, Nuraini Soleiman. "Analisis Butir Soal Pilihan Ganda Ujian Akhir Semester Mahasiswa Di Universitas Terbuka Dengan Pendekatan Teori Tes Klasik." Jurnal Pendidikan Terbuka dan Jarak Jauh 12, no. 2 (2011): 92-99.

Djemari Mardapi. Teknik Penyusunan Instrumen Tes dan Nontes. Yogyakarta: Mitra Cendikia, 2008.

Ebel, R.L. Essentials of educational measurement. 3rd ed. Englewood Cliffts, NJ: Prentice Hall Inc., 1972.

Fernandes, H.J. X. Evaluation of educational program. Jakarta: National Education Planning , Evaluating and Curriculum Development, 1984.

Irwan Fariza, Mohd Mahzan Awang, Abdul Razaq Ahmad. "The Relationship between Students' Involvement in 21st Century Classroom Learning Activities and Higher Order Thinking Skills (Hubungan antara Keterlibatan Pelajar dalam Aktiviti Pembelajaran Abad ke-21 dan Kemahiran Berfikir Aras Tinggi)." Jurnal Pendidikan Malaysia 44, no. 1 (2019): 59-64.

Karno To. Mengenal Analisis Tes Pengantar ke Program Komputer Anates. Bandung: FIP UPI, 2003.

Miftachul Ulum. BASIC STATISTIC With Statistical Package for Social Sciences (SPSS). 1 ed. Lamongan: CV. Pustaka Ilalang, 2020. 
EVALUASI, 5 (1), Maret 2021, ISSN 2580-3387 (print) |

ISSN 2615-2886 (online)

Homepage : http://e-journal.staima-alhikam.ac.id/index.php/evaluasi

DOI $\quad:$ http://doi.org/10.32478/evaluasi.v5i1.487

Article type : Original Research Article

---. Mahir Analisa Data SPSS Statistical Product, Service Solution. Yogyakarta: Ghaneswara, 2013.

Muslikah Purwanti. "Analysis Of Final Exam Questions In Financial Accounting Using Microsoft Excel 2010." Jurnal Pendidikan Akuntansi Indonesia XII, no. 1 (2014): 81-94.

Ngalim Purwanto. Prinsip-prinsip dan Teknik Evaluasi Pengajaran. Bandung: PT Remaja Rosdakarya, 2013.

Suharsimi Arikunto. Dasar-dasar Evaluasi Pendidikan. 2 ed. Jakarta: Bumi Aksara, 2013.

Sukardi. Evaluasi Pendidikan Prinsip dan Operasionalnya. Jakarta: Bumi Aksara, 2011.

Suryabrata, S. Pengembangan Alat Ukur Psikologis. Jakarta: Direktorat jenderal Pendidikan Tinggi: Departemen Pendidikan dan Kebudayaan, 1999.

Zainal Arifin. Evaluasi Pembelajaran. Bandung: PT Remaja Rosdakarya, 2013. 